University of Nebraska - Lincoln

DigitalCommons@University of Nebraska - Lincoln

RELATIONSHIP OF DAYLENGTH AND PROLACTIN TO RESUMPTION OF REPRODUCTIVE ACTIVITY IN ANESTROUS EWES

Bruce Schanbacher

USDA-ARS

Follow this and additional works at: https://digitalcommons.unl.edu/usdaarsfacpub

Part of the Agricultural Science Commons

Schanbacher, Bruce, "RELATIONSHIP OF DAYLENGTH AND PROLACTIN TO RESUMPTION OF

REPRODUCTIVE ACTIVITY IN ANESTROUS EWES" (1980). Publications from USDA-ARS / UNL Faculty. 759.

https://digitalcommons.unl.edu/usdaarsfacpub/759

This Article is brought to you for free and open access by the U.S. Department of Agriculture: Agricultural Research Service, Lincoln, Nebraska at DigitalCommons@University of Nebraska - Lincoln. It has been accepted for inclusion in Publications from USDA-ARS / UNL Faculty by an authorized administrator of DigitalCommons@University of Nebraska - Lincoln. 


\title{
RELATIONSHIP OF DAYLENGTH AND PROLACTIN TO RESUMPTION OF REPRODUCTIVE ACTIVITY IN ANESTROUS EWES ${ }^{1}$
}

\author{
Bruce Schanbacher \\ US Department of Agriculture 2,3 \\ Clay Center, NE 68933
}

\begin{abstract}
Summary
Concentrations of prolactin were measured in serum from three groups of Rambouillet ewes for 8 weeks to determine whether changes in prolactin concentrations were important during the transition from anestrus to seasonal breeding. Group I (control ewes) was maintained under conditions of natural daylength; group II (short-day ewes) was exposed abruptly on the longest day of the year to artificially shortened daylengths (8 hr light and $16 \mathrm{hr}$ darkness); group III (CB 154 ewes) was maintained similar to control ewes except each ewe received twice daily im injections of 2-bromo- $\alpha$-ergocryptine (CB 154). A fertile ram was kept with each group of ewes. Average serum prolactin remained above $200 \mathrm{ng} / \mathrm{ml}$ in control ewes throughout the 8-week study; however, short-day ewes had reduced $(\mathrm{P}<.05)$ serum prolactin and $C B 154$ ewes had low to nondetectable serum prolactin. Despite these differences, average interval to first estrus for the three groups of ewes was similar (control ewes, $25.2 \pm 3.0$; short-day ewes, $23.5 \pm 2.9$; СB 154 ewes, $26.4 \pm 4.3$ days). Short-day and CB 154 treatments did have an apparent effect on interval to conception. Of those ewes that lambed, short daylengths advanced $(\mathrm{P}<.01)$ the average date of conception by 7.7 days in relation to that of controls, whereas CB 154 treatment delayed
\end{abstract}

\footnotetext{
'The technical assistance of Ms. Becky Chmelka and Ms. Donna Taubenheim and cooperation of the Nebraska Agr. Exp. Sta., Univ. of Nebraska, Lincoln, is gratefully acknowledged.

${ }^{2}$ Roman L. Hruska US Meat Animal Research Center, Agr. Research, Science and Education Administration.

Mention of a trade name, proprietary product, or specific equipment does not constitute a guarantee or warranty of the product by the USDA and does not imply its approval to the exclusion of other products that may also be suitable.
}

$(\mathrm{P}<.01)$ the average date of conception by 8.4 days. All ewes exposed to short daylengths conceived at first estrus suggesting that this treatment may facilitate multiple lambing programs in Rambouillet flocks. In conclusion, high serum prolactin associated with anestrus is not a deterrent to the resumption of estrus and breeding activity in Rambouillet ewes and exposure to artificial lighting conditions may improve the reproductive performance of the breeding flock.

(Key Words: Anestrous Ewes, Estrous Cycles, Daylength, Prolactin.)

\section{Introduction}

A major restriction to intensifying lamb production is imposed by seasonal anestrus in ewes. In attempts to increase the productivity of each ewe in a flock, experiments have been conducted to elucidate how the environment modified ovarian cyclicity as assessed by anatomical, endocrinological and behavioral criteria. Daylength is the predominate environmental factor that regulates breeding activity in ewes (Marshall, 1937; Yeates, 1947); however, only recently have experiments been conducted to show the complexity of events that are necessary to activate the reproductive system in seasonal breeders. Manipulation of natural daylength and exposure to artificial photoperiods (light treatments) have been used to determine the possible constraints to multiple-lambing schedules. Experiments of Fraser and Laing (1969), Ducker and Bowman (1970a,b), Ducker et al. (1970a,b) and Newton and Betts (1972) showed the relationship between changing daylengths and cyclicity in ewes, i.e., decreasing daylengths promote the onset of estrus whereas increasing daylengths promote the likelihood of anestrus. The endocrinological basis for the light-dependent activation or deactivation of the estrous cycle, on the other hand, remains unsolved. Walton et al. (1977), after critically $293^{m}$ monitoring the changes in concentrations of 
$\mathrm{FSH}, \mathrm{LH}$, prolactin and progesterone in plasma of ewes during the transition from anestrus to fall breeding, suggested that a return to estrus and seasonal breeding may be brought about by the removal of an antigonadotropic effect exerted by high plasma concentrations of prolactin during the long days of spring and summer. This suggestion was supported by a premature decrease in plasma prolactin followed by an early return to estrus and ovulaticr in Clun Forest ewes exposed to short daylengths. In view of the inverse relationship observed between prolactin concentrations and gonadotropin-induced testicular function in rams (Lincoln et al., 1978; Sanford et al., 1978; Schanbacher and Ford, 1979) and hyperprolactinaemia-associated amenorrhoea which has been observed in women (Thorner et al., 1974), it was decided to investigate further the possible antigonadotropic effects of prolactin in anestrous sheep.

The objective of the present study was to test whether seasonally elevated prolactin concentrations cause a delayed return to estrus. Resumption of reproductive activity is reported in a group of anestrous Rambouillet ewes exposed abruptly to short daylengths or treated with 2-bromo- $\alpha$-ergocryptine, a potent inhibitor of prolactin secretion.

\section{Materials and Methods}

Animals. Thirty mature Rambouillet ewes that lambed in April and weaned their lambs on June 21 were assigned to the following study. Ewes were not cycling as indicated by the lack of breeding marks after exposure to vasectomized rams. Subsequently, they were randomly placed into one of three groups $(n=10)$. Group I ewes served as controls and were maintained outside under conditions of natural daylength throughout the study; ewes in group II were housed inside and exposed to artificially shortened daylengths of $8 \mathrm{hr}$ light and $16 \mathrm{hr}$ darkness; ewes in group III were maintained outside under conditions similar to those in group I, except that each ewe received a twice daily intramuscular injection of 2-bromo- $\alpha$ ergocryptine (CB 154). As shown for cyclic ewes (Niswender, 1974) and ram lambs (Revault et al., 1977), 1 to $2 \mathrm{mg}$ of ergocryptine per day is effective in reducing serum concentrations of prolactin. Therefore, $.5 \mathrm{mg}$ of ergocryptine dissolved in ethanol and $.9 \% \mathrm{NaCl}(60: 40, v / v)$ was injected morning and evening in group III ewes. Body weights were maintained nearly constant by restricted feeding.

The experiment was initiated for all 30 ewes on June 22 and continued for 8 weeks. A Rambouillet ram of proven fertility and acceptable libido was maintained with each separate group of ewes throughout the 8-week study. Rams were equipped with marking harnesses so that the incidence of estrus could be recorded on a daily basis. Rams and ewes were separated $a^{t}$ the end of the study (August 17), then all ewes were maintained outside until lambing time. Routine lambing data were recorded to determine the exact date of conception and to look for any potentia! side effects of short daylengths or ergocryptine treatment on lamb survival.

Blood Samples and Radioimmunoassaj's. Beginning June 22, single blood samples were collected by jugular venipuncture from each ewe at weekly intervals. The samples were collected between 0900 and $1000 \mathrm{hr}$, kept 2 to $4 \mathrm{hr}$ at $4 \mathrm{C}$, then harvested after centrifugation at $1,500 \times g$ for $20 \mathrm{~min}$ at $4 \mathrm{C}$. Sera were stored at $-20 \mathrm{C}$ until assayed.

Prolactin concentrations were determined by the double antibody radioimmunoassay procedure described by Schanbacher and Ford (1979) without modification. NIH-P-S8 was used as the reference standard. Progesterone was estimated by the method of Schanbacher (1979), which is a modification of the direct radioimmunoassay procedure of Terqui and Thimonier (1974). Concentrations greater than $.6 \mathrm{ng} / \mathrm{ml}$ were associated with apparent luteal function; therefore, ewes whose serum contained greater than $.6 \mathrm{ng} / \mathrm{ml}$ were classified as ewes expressing ovarian cyclicity. Anestrous ewes and ewes near the time of estrus had serum progesterone concentrations between .1 and .3 $\mathrm{ng} / \mathrm{ml}$.

Students $t$-test and analysis of variance were used for statistical comparisons.

\section{Results}

Serum Prolactin. The effect of abrupt exposure to short daylengths or treatment with ergocryptine on serum prolactin concentrations is shown in figure 1. All ewes had relatively high prolactin concentrations in serum at the beginning of the study; however, short daylengths caused prolactin to decrease $(P<.05)$ in relation to that of control ewes. As suggested by the means and standard errors, considerable ewe-to-ewe variation was observed. Ewes treated with ergocryptine had low to nondetec- 


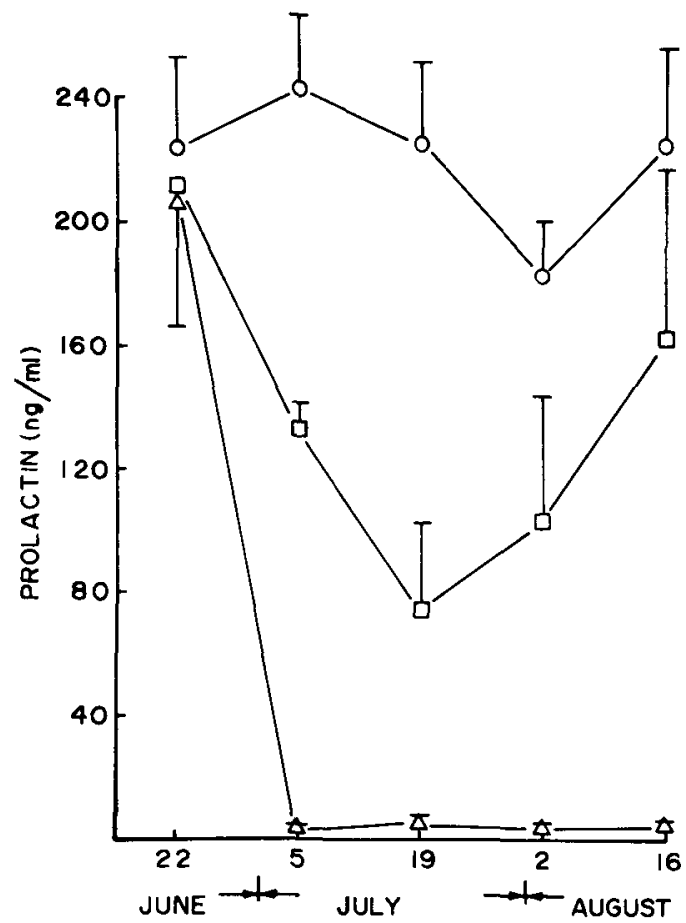

Figure 1. Serum prolactin concentrations in ewes exposed to natural $(O)$ or artificially shortened ( $\square$ ) daylengths or treated twice daily with ergocryptine $(\Delta)$. Short daylengths comprised of $8 \mathrm{hr}$ light and 16 hr darkness beginning at 0700 hour. Ergocryptine was administered at $.5 \mathrm{mg}$ per injection. Values represent the mean \pm SEM for 10 animals.

table concentrations of prolactin in serum. Prolactin concentrations were increased at the end of the experiment in sera from ewes in groups I and II for no apparent reason.

Serum Progesterone. All except four ewes had low progesterone concentrations at the beginning of the study and were judged to be acyclic (figure 2). Thereafter, progesterone increased in the majority of ewes indicating enhanced ovarian activity. Progesterone fluctuated between 1 and $2 \mathrm{ng} / \mathrm{ml}$ for ewes with apparent luteal function, but otherwise was less than $.3 \mathrm{ng} / \mathrm{ml}$. On the basis of serum progesterone concentrations, the majority of ewes had silent ovulations preceding their first behavioral estrus and then cycled normally until the end of the experiment or until they had conceived.

Estrous Activity and Conception. Not all ewes expressed estrus during the 8 week study (figure 2 and table 1). Although all ewes exposed to short daylengths were mated, only nine of 10 control ewes and eight of 10 CB 154

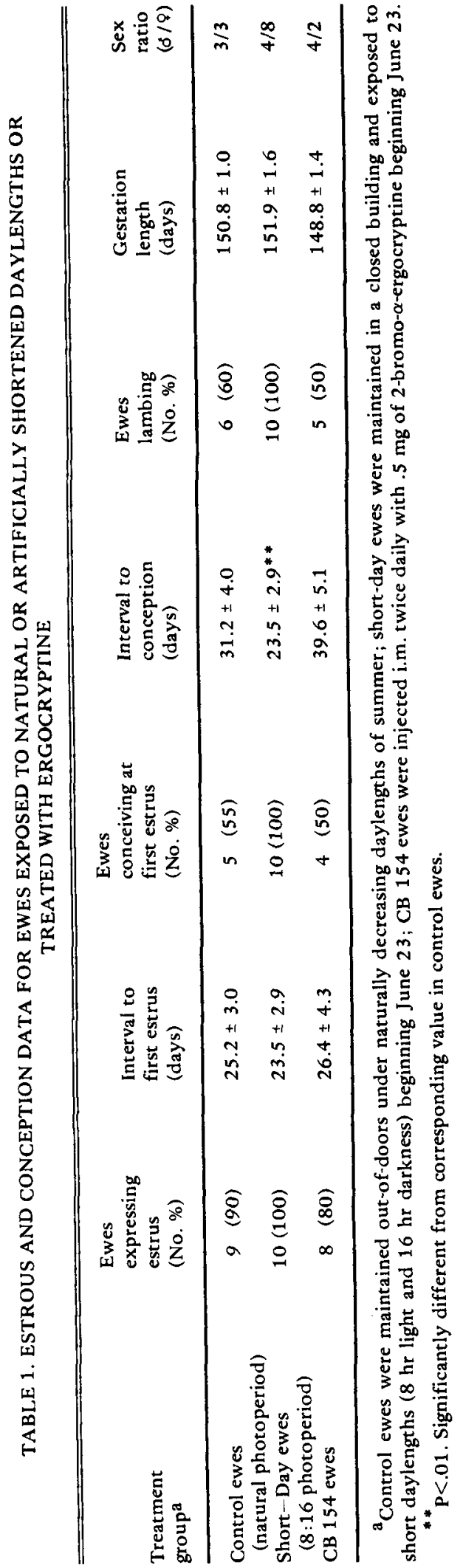




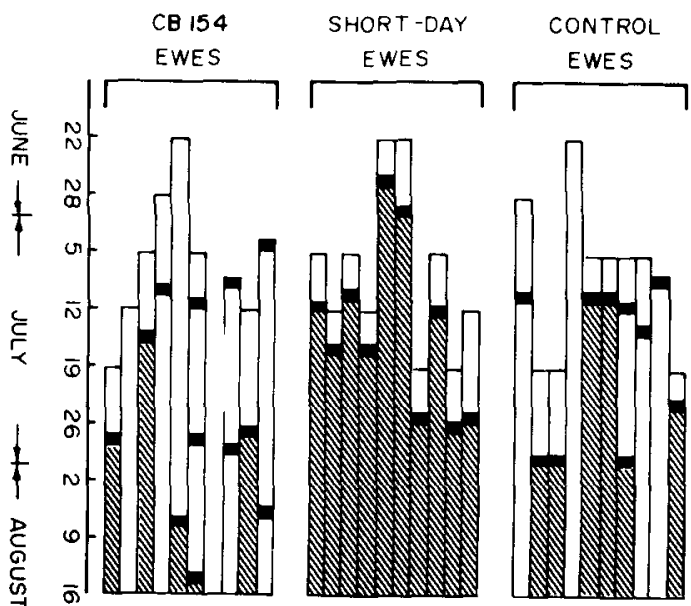

Figure 2. Bar graph depicting the resumption of reproductive activity in ewes exposed to natural or artificially shortened daylengths or treated twice daily with ergocryptine (CB 154). The open bar represents when ovarian activity was initiated as indicated by increased serum progesterone concentrations. The dark square within each bar represents behavioral estrus as indicated by breeding marks from fertile rams. The hatched portion of each bar indicates that the particular ewe had conceived.

ewes were detected in estrus by the breeding rams. Of those rams expressing estrus, the interval from the beginning of the study (June 22) to first estrus was similar for the three groups of ewes even though short-day ewes were earliest $(23.5 \pm 2.9$ days). On the basis of lambing records (table 1), all short-day ewes conceived at first estrus, but only about $50 \%$ of control and CB 154 ewes conceived at first estrus. Six of 10 control ewes and 5 of $10 \mathrm{CB}$ 154 ewes conceived and lambed subsequent to the 8-week exposure to breeding rams. Average interval to conception was shorter $(P<.01)$ for CB 154 ewes than for control ewes. Lambing records did not suggest a detrimental effect of treatment on gestation length or lamb viability.

\section{Discussion}

The results of this study indicate that seasonal anestrus in sheep is accompanied by increased serum prolactin concentration. Furthermore, exposure to artifically shortened daylengths or treatment with ergocryptine reduces the high prolactin concentrations found in ewes during the summer months. This finding was similar to that observed in other studies in which ewes (Walton et al., 1977) and rams (Pelletier, 1973; Lincoln et al., 1978;
Sanford et al., 1978; Schanbacher and Ford, 1979) were subjected to short daylengths.

The rate at which prolactin decreases following exposure to short daylengths probably depends on the relative change in daylength and on the breed of sheep used in the test situation. Rambouillet ewes, which resume estrous activity early in the breeding season, were slow to respond to the change in daylength and maintained relatively higher serum prolactin under the 8:16 light:dark photopheriod in this study than Clun Forest ewes (Walton et al., 1977). Walton et al. (1977) noted that the first ovulation during the breeding season of Clun Forest ewes only occurred after the seasonal decline in plasma prolactin. While this situation may hold true for several breeds, Rambouillet ewes in the present study were showing ovarian cyclicity and estrous behavior in July when prolactin levels were still high. It is attractive to postulate an inherent breed difference in the ability to respond to changing daylengths regardless of the possible influences of prolactin. Although this hormone was not measured in a light controlled experiment by Vesely (1978), it was shown that conception rates were affected in Suffolk ewes but not Rambouillet ewes when bred during a period of short daylengths that had been preceded by long daylengths.

The possible antigondotropic effects of prolactin on reproductive activity of anestrous ewes were further assessed after treatment with ergocryptine. This drug has not only been used to suppress prolactin secretion in laboratory animals (Fluckiger and Wagner, 1968), but also in mature cyclic ewes (Niswender, 1974) and in ram lambs (Ravault et al., 1977). As shown in figure 1, ergocryptine was quite effective in reducing serum prolactin during summer anestrus; yet average interval to first estrus was almost identical to that recorded for control ewes. Therefore, prolactin is not antagonistic to ovarian cyclicity because its presence or removal did not hasten the onset of estrus. Niswender (1974) presented similar data showing that prolactin does not play a role in the regulation of luteal function in normal cycling sheep. The interval to conception, on the other hand, was greater in CB 154 ewes than in control ewes. The interpretation regarding interval to conception is difficult to assess with the limited number of animals involved. A direct effect of ergocryptine on conception or pregnancy maintenance cannot be ruled out.

The most important finding in this study 
may be the ability of ewes to conceive at first estrus and maintain pregnancy after abrupt exposure to short daylengths. However, because these data are confounded by possible differences in both location and individual ram effects, these studies should be replicated under more precisely controlled conditions to determine the cause of this effect. Application of light control to intensify lamb production has already received some attention (Robinson, 1974; Vesely, 1975, 1978). Caution regarding the interpretation of estrus induction and conception by specific light treatments to ewes at various times of the year or from one year to the next, however, should be taken. Major differences in reproductive performance of experimental ewes may be due to seasonal or individually imposed differences in ram fertility (Schanbacher, 1979). Because fertility of the breeding ram can be improved by exposure to short daylengths, perhaps the conception rates in the short-day ewes of the present study can be accounted for in part by the ram. Further experimentation is needed to determine the possible constraints of both ram and ewe to intensification of lamb production.

\section{Literature Cited}

Ducker, M. J. and J. C. Bowman. 1970a. Photoperiodism in the ewe. 3. The effects of various patterns of increasing daylength on the onset of anoestrus in Clun Forest ewes. Anim. Prod. 12:465.

Ducker, M. J. and J. C. Bowman. 1970b. Photoperiodism in the ewe. 4. A note on the effect on onset of oestrus in Clun Forest ewes of applying the same decrease in daylength at two different times of the year. Anim. Prod. 12:513.

Ducker, M. J., C. J. Thwaites and J. C. Bowman. 1970a. Photoperiodism in the ewe. 1. The effect of long supplemented daylengths on the breeding activity of pregnant and non-pregnant TeeswaterClum ewes. Anim. Prod. 12:107.

Ducker, M. J., C. J. Thwaites and J. C. Bowman. $1970 \mathrm{~b}$. Photoperiodism in the ewe. 2 . The effects of various patterns of decreasing daylength on the onset of oestrus in Clun Forest ewes. Anim. Prod. 12:115.

Fluckiger, E. and H. R. Wagner. 1968. 2-Br- $\alpha$-ergokryptin: Beeinflussung von fertilitat und laktation bei der ratte. Experientia 24:1130.

Fraser, A. F. and A. H. Laing. 1969. Oestrus induction in ewes with standard treatments of reduced natural light. Vet. Rec. 84:427.

Lincoln, G. A., A. S. McNeilly and C. L. Cameron. 1978. The effects of a sudden decrease or increase in daylength on prolactin secretion in the ram. J. Reprod. Fertil. 52:305.
Marshall, F.H.A. 1937. On the change over in the oestrous cycle in animals after transferance across the equator, with further observations on the incidence of the breeding seasons and the factor controlling sexual periodicity. Proc. R. Soc. B. $122: 413$.

Newton, J. E. and J. E. Betts. 1972. A comparison between the effect of various photoperiods on the reproductive performance of Scottish halfbred ewes. J. Agr. Sci., Camb. 78:425.

Niswender, G. D. 1974. Influence of 2-Br- $\alpha$-ergocryptine on serum levels of prolactin and the estrous cycle in sheep. Endocrinology 94:612.

Pelletier, J. 1973. Evidence for photoperiodic control of prolactin release in rams. J. Reprod. Fertil. $35: 143$.

Ravault, J. P., M. Courot, D. Garnier, J. Pelletier and M. Terqui. 1977. Effect of 2-bromo- $\alpha$-ergocryptine (CB 154) on plasma prolactin, LH and testosterone levels, accessory reproductive glands and spermatogenesis in lambs during puberty. Biol. Reprod. 17:192.

Robinson, J. J. 1974. Intensifying ewe productivity. Proc. Brit. Soc. Anim. Prod. 3:31.

Sanford, L. M., D. B. Beaton, B. E. Howland and W. $M$. Palmer. 1978. Photoperiod-induced changes in LH, FSH, prolactin and testosterone secretion in the ram. Can. J. Anim. Sci. 58:123.

Schanbacher, B. D. 1979. Increased lamb production with rams exposed to short daylengths during the nonbreeding season. J. Anim. Sci. 49:927.

Schanbacher, B. D. 1979. Radioimmunoassay of ovine and bovine serum progesterone without extraction and chromatography. Endocrine Res. Commun. $6: 277$.

Schanbacher, B. D. and J. J. Ford. 1979. Photoperiodic regulation of ovine spermatogenesis: Relationship to serum hormones. Biol. Reprod. 20:719.

Terqui, M. and J. Thimonier. 1974. Nouvelle methode radioimmunologique rapide pour l'estimation du niveau de progesterone plasmati-que. Application pour le diagnostic precoce de la gestation chez la brebis et la chevre. C. R. Acad. Sci. Paris, Ser D. 279:1109.

Thorner, M. O., A. S. McNeilly. C. Hagan and G. M. Besser. 1974. Long term treatment of galactorrhoea and hypogonadism with bromocryptine. Brit. Med. J. ii:419.

Vesely, J. A. 1975. Induction of lambing every eight months in two breeds of sheep by light control with or without hormonal treatment. Anim. Prod. $21: 165$.

Vesely, J. A. 1978. Application of light control to shorten the production cycle in two breeds of sheep. Anim. Prod. 26:169.

Walton, J. S., J. R. McNeilly, A. S. McNeilly and F. J. Cunningham. 1977. Changes in concentrations of follicle-stimulating hormone, luteinizing hormone, prolactin and progesterone in the plasma of ewes during the transition from anoestrus to breeding season. J. Endocrinol. 75:127.

Yeates, N.T.M. 1947. Influence of variation in length of day upon the breeding season of sheep. Nature, London 160:429. 